\title{
Co-Leadership in Climate Change: An Agenda to 2013 and Beyond
}

\author{
GODWELL NHAMO*
}

\begin{abstract}
The climate change (CC) discourse has moved from the dominance of science into other contesting spaces that include politics, economics, religion, social justice and the business arena. Two questions are addressed in this paper: (1) which actors (human), actants (non-human) and networks have been and are shaping the CC narrative? (2) Who could be the appropriate leaders and leadership models to address the challenges associated with CC in our times? Powerful scientific, political and economic groupings spearheading the CC agenda have emerged. To this end, co-leadership might be an appropriate model for addressing CC in this century. A co-leadership model recognizes the existence and interface of leaders and co-leaders. In CC co-leadership places this narrative at the centre, driving various kinds of leaders and co-leaders as well as leadership and co-leadership tied to numerous CC leadership zones. Among some of the leadership zones are mitigation, adaptation, financing, technology, social dynamics, and policy framework. The entire work is informed by an analytical framework that permits documentation, understanding and tracing of actors, actants and networks, thus, the Actor/Actant Network Theory.
\end{abstract}

\section{Introduction}

The effective exercise of leadership must, in part, be based on as thorough an understanding as possible of objective reality. (Former President Thabo Mbeki, 23 September 2009)

The above statement was made during former South African President Thabo Mbeki's public lecture at the University of the Witwatersrand. The public lecture was centred on 'The Effective Exercise of Leadership' with a focus on the future role of the youth (Globler, 2009). It is in line with the above quote that this paper was prepared with the intention to conceptualize a possible appropriate leadership model for addressing climate change (CC) now and beyond 2012. The year 2012 will witness the end to the Kyoto Protocol framework that stipulated a need for the developed countries to collectively reduce greenhouse gas (GHG) emissions by an average 5.2\% between 2008 and 2012 based on 1990 emission levels.

The Kyoto Protocol framework, signed in 1997 and ratified in February 2005, spells out a CC leadership model dominated by countries of the North. By outlining GHG emissions targets for developed countries (referred 
to in the Protocol as Annex 1), the framework inevitably created a CC leadership bias towards powerful nations. The developing countries are mentioned in the Kyoto Protocol as host countries for Clean Development Mechanism (CDM) projects that earn credits for the investing Annex 1 country. It therefore comes as no surprise that powerful CC leadership has emerged from Annex 1 countries including the UK and the EU trading bloc.

There is also leadership dominance from the developed North in terms of representation in international bodies dealing with CC governance. Some of the global CC governance platforms of interest are the United Nations Framework Convention on Climate Change (UNFCCC), the Intergovernmental Panel on Climate Change (IPCC), United Nations Environment Programme (UNEP) and the International Energy Agency (IEA). The UNFCCC stands out as the key body providing CC leadership and governance. It is the formal structure with which CC issues are presented, debated, and negotiated and positions set. There is also dominance by the powerful rich nations in international bodies, such as the World Bank and the International Monitory Fund (IMF), which are not directly linked to CC governance but have a bearing on how proceedings are managed. Hence we have witnessed recent and protracted calls by countries of the South for their reform.

Apart from the CC leadership provided by organizations highlighted earlier, there has been recognition of CC leadership from individuals like former UK Prime Minister Tony Blair, former US Vice-President Al Gore, Sir Nicholas Stern and, the current US President Barack Obama. The global system has structured a reality whereby CC leadership from emerging economies, such as the group of five (G5) that include Brazil, India, China, Mexico and South Africa, is somehow undermined. Brazil's pre-Kyoto Protocol proposal on the Clean Development Fund (CDF) based on the polluter-pays principle, for example, was dismissed by the USA, Australia, New Zealand and other developed countries. The CDF was reincarnated as the market based Clean Development Mechanism (CDM) under the present day Kyoto Protocol (Nhamo, 2006a, p. 10). Brazil had proposed then that a US\$3 per tonne be charged to all the countries that surpassed their $\mathrm{GHC}$ emission quotas towards the CDF. Such funds would then be distributed for use by the developing countries that were contributing less towards global warming and CC to address their environmental challenges.

Recognizing the roles and responsibilities that developing countries might have in addressing CC is the reason why a case for co-leadership in CC is presented in this paper. Given the complexity and contested nature of CC, a monopolistic approach to leadership might not be the best now and in the future. CC leadership must be devolved, decentralized and honestly shared 
between the rich and the poor nations as well as leaders from the two divides.

Drawing from the Actor/Actant-Network Theory (AANT) (Nhamo, 2006b, p. 34-47), this paper seeks to document, understand and follow key actors, actants and their networks in terms of CC leadership. The main objective is to conceptualize a CC leadership model that might be appropriate as an agenda for 2013 and beyond. Co-leadership in CC is proposed and deliberated upon as the preferred model.

\section{Research and analytical framework}

The complexity of the twin concepts under investigation-CC and leadership means one has to utilize an appropriate hybrid theoretical and analytical frame- work. In this case, the Actor/Actant Network Theory (AANT) as popularized by Godwell Nhamo (Lotz-Sisitka, 2006b, p. 5) was a preferred choice. Two questions are investigated in the paper: (1) which actors, actants and networks have been and are shaping the CC narrative? (2) Who and what could be the appropriate leaders and leadership models to address the challenges associated with $\mathrm{CC}$ in our times?

A detailed discussion on AANT has been carried out in a separate paper entitled Actor/Actant-Network Theory as Emerging Methodology for Environmental Education Research in Southern Africa', published in the Southern African Journal of Environmental Education (Nhamo, 2006b, pp. $34-47)$. The editor dedicated the entire edition to issues surrounding actors, actants and networks following the central theme from the mentioned paper (Lotz-Sisitka, 2006b,pp. 5-9). Hence, a synopsis of AANT is presented for the purposes of this work and readers are referred to the said article for more insights on the theory and associated methodological underpinnings.

According to Nhamo (2003; 2006b), AANT was conceptualized drawing largely from the work by Callon and Latour that focused on ActorNetworkTheory (Callon \& Latour, 1981; Callon, 1986; 1991; 1999; Latour, $1986 ; 1999)$. A number of other authors also make reference to ActorNetwork Theory as proposed and solidified by Callon and Latour (1981), including Davies (2002), Fountain (1999), Gaskell and Hepburn (1998), Keeley and Scoones (2003), Law (1999), Williams-Jones and Graham (2003), Singleton and Michael (1993) and Tatnall and Gilding (1999).

In AANT the aspect of language, including the use of symbols, is critical. A particular set of actors and related networks use a particular language and symbols in their communication that includes verbal and documentation. Language can be (mis)used as a tool of exclusion and inclusion. The next few paragraphs will briefly discuss language and symbols used in 
communicating global warming and CC. The language and symbols might differ slightly at the global and national scales, although many common terms are now used in the networks at these levels.A number of abbreviations, too many to list here, have been popularized in the global warming and CC narrative. Some of the most commonly used include GHG (greenhouse gas), IPCC (Intergovernmental Panel on Climate Change), IEA (International Energy Agency), GWP (Global Warming Potential of GHGs), UNFCCC (United Nations Convention on Climate Change), KP (Kyoto Protocol), CDM (Clean Development Mechanism), JI (Joint Implementation), ET (EmissionTrading), EU-ETS (European Union Emissions Trading Scheme), CCS (carbon capture and storage), $\mathrm{CO}_{2}$ (carbon dioxide), $\mathrm{CO}_{2} \mathrm{e}$ (carbon dioxide equivalent), Gt (Giga tonnes), ppm (parts per million of $\mathrm{CO}_{2}$, currently estimated at an average of 350), and EE (energy efficiency). Some of the abbreviations and symbols are highly localized and include: the LTMS (Long Term Mitigation Strategy) for South Africa; in China, the CCLC (Climate Change Leading Group); in the UK the symbol 10:10 (10\% reduction in GHGs by 2010); and in the EU the symbols 20:20 (20\% reduction in GHGs by 2020). Other terms commonly used include: carbon (credits); carbon footprint; peak, plateau and decline (this is in reference to GHC emissions into the future); required by science (now accepted as the need to keep GHG emissions to $2 \%$ below pre-industrial levels); transition to low carbon; low carbon economies; green buildings; emerging economies; climate negotiations (one also hears a lot said about the UK, EU, USA, China, India, and negotiation teams and groupings); Copenhagen 2009; scenario; climate regulation;per capita emissions; and green jobs. For those outside the global warming and CC space and networks, it becomes difficult to relate to issues discussed in that space.

Narratives surrounding global warming and CC are not without tensions, debates and responses. This is due to the number of actors (human) and actants (non-human) involved in the discourse. Such actors and actants are visible at three levels: the global, regional and national. Hence AANT provides a hybrid analytical framework for interrogating the complex and contested phenomena under investigation. The discipline of environmental policy also brings into play the notion of stakeholders (Nhamo, 2008) who compete for policy space as led by selected policy entrepreneurs (Keeley \& Scoones, 2003, p. 35). Such policy entrepreneurs know when to push for a policy position as well as when to stop. This is repeatedly done until a policy position is reached with coalitions and networks having been formed. To understand and comprehend this fully, one needs to have experienced CC negotiations, such as Copenhagen 2009.

Four pillars are noticeable in AANT: these include the fact that (1) there exists a relational orientation within phenomena under study, (2) binaries and disciplines need to be collapsed, (3) there are actors, actants and actor/actant-networks, and (4) that data is interpreted through the use of 
moments of translation' (Nhamo, 2006b, p. 35). Writing on relational orientation, Latour (1993, p. 55) identifies what he terms quasi-objects (hybrids or tokens):

Quasi-objects are in between and below the two poles [nature pole and subject/society pole], at the very place around which dualism and dialectics had turned endlessly without being able to come to terms with them. Quasiobjects are much more social, much more fabricated, much more collective than the 'hard' parts of nature, but they are in no way arbitrary receptacles of a full-fledged society. On the other hand they are much more real, nonhuman and objective than those shapeless screens on which society-for unknown reasons - needed to be 'projected' (Latour, 1993, p. 55).

The global warming and CC narrative becomes such a token, which is simultaneously real, discursive, contested and socially constructed. In line with the need to collapse binaries, one cannot therefore talk of the global versus the regional actors and actants, or the global versus the national, or the national versus the regional. Such distinction becomes blurred in AANT as well as the CC space. In CC what happens at the global level influences the regional and the local, and vice versa. This is the reason why stronger voices from Africa, Brazil, China, India and South Africa emerged during the Copenhagen Climate Change Summit that took place in December 2009. Developing countries have formed strong coalitions to ensure that their voices are heard as they are also the most vulnerable to climate variability and change.

From a global warming and CC horizon, three sets of actors and actants are identifiable and, as already mentioned, include the global, regional and national. These actors and actants interact in space to shape global warming and CC as a 'quasi-object' or 'token'. Further details regarding how the three sets of actors and actants identified interact in space and how they shape CC leadership at all levels, including the localized scale, are shown in Figure 1. It is important to note that inherent in the arrangement of the identified three sets of actors and actants are networks pushing for different understanding of the subject matter as they have interacted in space and time to shape the Kyoto Protocol as well as the ongoing negotiations for a new climate deal after 2012.

Some of the global actors, actants and related networks include the IPCC, AlGore, Tony Blair, UNFCCC (including its Conference of Parties, abbreviated and popularized as CoP, and the Meeting of Parties, popularized as MoP), the KyotoProtocol, the UN Leadership Forum on Climate Change, the United Nations Environment Programme, The Bali Communiqué, The Poznan Communiqué, the Copenhagen Climate Council, The Copenhagen Call, The Copenhagen Communiqué on Climate Change, A Copenhagen Climate Treat by the NGO Coalition, the Climate Change 
Roundtable of Business Representatives, the World Business Summit on Climate Change, the World Business Council on Sustainable

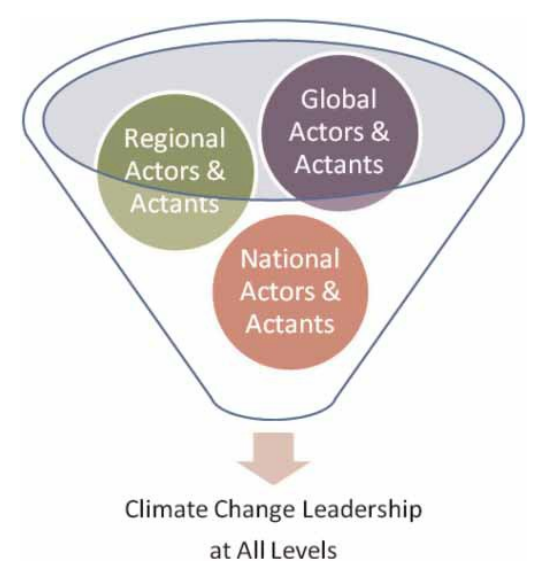

Figure 1. Actors and Actants in CC

Development, the World Wide Fund's (WNF) New Climate Deal Pocket Guide, the $\mathrm{G} 8, \mathrm{G} 13$ and, recently, the $\mathrm{G} 22$. At the regional level, the key negotiating blocs are the Africa Group, the Alliance of Small Island States (AOSIS), the Environmental Integrity Group, the European Union, the Umbrella Group, the European Union \& Umbrella Group, the G77, G77 $\mathrm{P}$ China, the Least Developed Countries (LDCs) and the Organization of the Petroleum Exporting Countries (OPEC) (Shanahan, 2007 , pp. $55-65$ ). There are other informal groupings, among them the G5, comprising Brazil, China, India, Mexico and South Africa; the G8; the G8 P 5 (G13); and the G20. In addition, bilateral arrangements and treaties, such as the China-India Climate Agreement, emerged in the leadup to Copenhagen.

At the national level there are various actors and actants, including, in particular, non-governmental organizations (NCOs) and their groupings. Of late there have been climate leadership groups formed by business or coalitions of business, labour and government. Examples of such groups include: the National Business Initiative's Climate Change Working Group (South Africa); the Climate Change Leading Croup (China); the Business Environmental Leadership Council (USA); the Climate Change Leadership Forum (New Zealand); US President Barack Obama's October 2009 Energy Month Declaration; the Corporate Leaders' Group on Climate Change and Project 10:10 (UK) as well as the Ethos Institute'sBrazil 2020 Climate Leadership Campaign. 
The picture emerging from the global, regional and national initiatives high-lighted above shows complexity. The key sources of data and information for such have been mainly actants such as position papers, policy documents and the Internet. Tracing these documents and their production is part of the methodological set-up entrenched in AANT. This allowed the author to map major actors and related actants and conceptualize new horizons and frameworks to understand, inform and analyse leadership in general as well as co-leadership in CC as central theme of this paper.

\section{Leadership}

What then is leadership? This is one of the most profound questions asked in this political science. Many positions of leadership are contested. The same kind of contest also exists in trying to understand what leadership means. Trying to define leadership can be a futile exercise. It is difficult to come up with a precise definition of leadership. My intention here is not to go against this observation. What this paper does, however, is to bring up some indicators of leadership. Going back to Mbeki's public lecture, the former president declared that most economists had failed to predict the global financial crisis, and therefore did not provide the necessary effective leadership. Mbeki went on to cite the 2009 speeches by two central bank chiefs, Ben Bernanke of the USA and Tito Mboweni of South Africa (Globler, 2009). The emphasis here is not on the financial crisis but on leadership. In a 2004 review of leadership theory, Northouse (cited in Bolden, 2004, p. 5) identified four common themes in how leadership is conceived namely: (1) leadership is a process; (2) leadership involves influence; (3) leadership occurs in a group context; and (4) leadership involves goal attainment. A number of default aspects are invoked when we talk of leadership. We see a person or institution well ahead of others. This person or institution must be infront somehow. We see the knowledge, understanding and wisdom of the leader and the institutions in which the leader is embedded. More so, we see a politician. But, leadership cannot be only from the front. There are leaders and leadership institutions that make an impact from behind and from the middle. This implies that leaders and leadership can emerge from three compartments: the front, middle and at the back. Leaders must be found in all ranks - shop floor, middle level and the top brass. I then see man and women as well as their institutions whose purpose of life is the life of purpose. They can steer the CC ship away from the storm to safety. However, do we have such men and women who remain standing in the battle against the storm of global warming and CC? Tohelp us understand this complex subject, a number of leadership theories and models will now be presented. 


\section{Leadership models}

In the twentieth century leaders were identified by certain traits (Philips, 2009 , p. 4) and long lists of such leadership traits have emerged, including one by Stogdill $(1974$, p. 81), which identifies the following:

1. Strong drive for responsibility

2. Focus on completing the task

3. Vigour and persistence in pursuit of goals

4. Adventure and originality in problem-solving

5. Drive to exercise initiative in social settings

6. Self-confidence

7. Sense of personal identity

8. Willingness to accept consequences of decisions and actions

9. Readiness to absorb interpersonal stress

10. Willingness to tolerate frustration and delay

11. Ability to influence the behaviour of others, and

12. Capacity to structure social systems to the purpose in hand (see, for example, Oltmann, 2008, p. 2).

An alternative to the trait of leadership characterization emerged as a call to con- sider leadership styles and behaviours. This approach meant considering what leaders actually do, rather than their underlying characteristics (Bolden, 2004, p. 9). Drawing from the Biblical times, Arendt makes three up-front observations that: there is not one single kind of leadership style; there is a need for various kinds of leaders and that it is paramount that these leaders be apportioned appropriate roles; and that a good leader can be identified as a follower who tries to bring the best out of what one intends to achieve (Arendt, 2007, p. 1). The observation that there is a need for many types of leaders brings us closer to the thesis and concept of co-leadership. From the above premises, 10 kinds of leadership models are drawn. The Visionary Leader leads by building new initiatives from the beginning. The Political Leader leads by deceitfulness and often through secret alliances. The Teaching Leader leads by ideas and ethical principles. The Youthful Leader leads by energy and vitality. The Spiritual Leader leads by being devout. The Inherited Leader leads by default or inheriting the position. The Military Leader leads by commands or decrees. The Administrative Leader leads by policies. The Greedy or Selfish Leader leads by what benefits they can get for themselves. The Mentoring Leader leads by coaching and delegation.

Before addressing leadership styles and theories associated with them, Gill (2006, pp. 16-22) ventures into areas where leadership is exercised. These areas as identified include leadership in the public sector, in business, in the military and in the arts. In my view, CC leadership cuts across the four sectors identified. Gill (2006, p. 44) goes further and talks of leadership styles, namely: directive, consultative, participative, negotiative 
and delegative. An Action-Centred Leadership model that resides at the nexus of a task, the team, and the individual is also highlighted. In line with structures and institutional heads, Lotz-Sisitka (2006a, p. 27) mentions xtructural leadership as a type of leadership that is needed to drive the United Nations Decade of Education for Sustainable Development (UNDESD) running up to 2014.

Billsberry (2009, pp. $24-25$ ) is content that leadership is a contested construct. In doing so, he draws from Grint's division of leadership theories that include situational, constructive, contingent and trait. However, Heenan and Bennis (1999, p. 10) are quick to contest this and say all leadership is situational. Drawing on the fact that there is no one, single kind of leadership style, situational leadership theories were developed. These indicated that the 'leadership style to be used is dependent upon such factors as the situation, the people, the task, the organisation, and other environmental variables' (Bolden, 2004, p. 10). Aligned to situational leadership family are: a continuum of leadership styles from autocratic to democratic (see for example Philips, 2009, p. 6); action-centred leader- ship; the transformational approach; the transactional approach; charismatic leadership; and distributed leadership (also known as informal, emergent or servant and team leadership). In another work, the author elaborates on leadership development (Bolden, 2005). In his concluding remarks, Bolden (2004, pp. 28 -29) presents insights regarding the changing face of leadership in the twenty-first century. Leadership of this century is seen as the key to organizational success (see for example Philips, 2009, pp. $8-12$ ). Bolden notes that although the fundamental qualities and values of leadersare likely to remain unchanged, the manner and mix in which they are exhibited needs to become more flexible and aligned to the context. In the author's words:

The leader needs to become increasingly adaptable-making sense of uncertainty and mana- ging complexity. The qualities of openness, empathy, integrity and self awareness are coming to the fore and demand a more participative leadership style, whereby the leader not only involves colleagues, but listens, is responsive to feedback and delegates responsibility. The leader will increasingly need to 'win the right to lead', 'lead from the front', 'lead by example' and be prepared to 'share in hardship'. (Bolden, 2004, p. 28)

It is possible to conceptualize a CC leadership model around the models discussed above. The next section will deliberate on this subject. Emerging issues will be used to identify and characterize some of the leadership and leadership models that have surfaced to deal with CC leading to 2013 and beyond. 


\section{Conceptualizing CC leadership models}

In this section, the CC leadership models are presented and a conclusion is reached that co-leadership might be the appropriate model now and into the future. The section is divided into three main parts looking at: CC torch-bearers and champions; co-leaders(hip); and a co-leadership model for CC governance.

\section{$\mathrm{CC}$ torch-bearers and champions}

In this section, I will consider selected examples of CC torch-bearers and champions by profiling the United Nations Framework Convention on Climate Change (UNFCCC) and the Intergovernmental Panel on Climate Change (IPCC). The UNFCCC is probably one of the most cited institutions within the field of CC. The leadership had the vision to break away from tradition and announce that CC was mainly caused by humaninduced GHGs, chief among them carbon dioxide. Although opposing forces tried to close the debate, fearing the litigation potential, the UNFCCC remained resolute, and today the world is rallying behind the narrative and a need to urgently address probably the greatest challenge in human history. The UNFCCC has stood the test of time as global leaders now recognize its authentic leadership. The C20 leadership had this to say regarding the UNFCCC in reference to ongoing negotiations leading to Copenhagen: 'We will spare no effort to reach agreement in Copenhagen through the United Nations Framework Convention on Climate Change (UNFCCC) negotiations' (G20, 2009, p. 4). The $G 20$ leaders reaffirmed the objectives, provisions and principles of the UNFCCC:

As leaders of the world's major economies, we are working for a resilient, sustainable, and green recovery. We underscore anew our resolve to take strong action to address the threat of dangerous climate change. We reaffirm the objective, provisions, and principles of the United Nations Framework Convention on Climate Change (UNFCCC), including common but differentiated responsibilities. We will intensify our efforts, in cooperation with other parties, to reach agreement in Copenhagen through the UNFCCC negotiation. An agreement must include mitigation, adaptation, technology, and financing. (G20, 2009, p. 15)

Both the IPCC and former US Vice-President Al Gore shared the Nobel Peace Prize in 2007. This was in recognition of their work that provided decision-makers and the general public globally with the best possible scientific foundation, enhancing knowledge, understanding and wisdom combating the increasing threat from CC (UNEP, 2009, p. 4). The IPCC was jointly established in 1988 by the World Meteorological Organization 
(WMO) and the United Nations Environment Programme (UNEP), and has approximately 2,500 members. This special group of leaders have seen it all: from the sceptics and dissidents who had a strong voice, determined and well resourced, to dismiss the phenomenon, to a world that is now receptive and has a better understanding of the subject matter. The IPCC is headed by a plenary consisting of WMO and UNEP member countries. Below are the bureau and the IPCC secretariat, with head offices at the WMO in Geneva. The higher tiers oversee three working groups:

- Working Group I assesses physical scientific aspects of the climate system and CC.

- Working Group II evaluates the vulnerability of socio-economic and natural systems to climate change, the negative and positive consequences, and options for adapting to it.

- Working Group III looks at options for mitigating CC through limiting or pre- venting GHC emissions and enhancing activities to remove them from the atmosphere. (UNEP, 2009, p. 5)

Each of the three working groups has produced reports within their specialization areas since 1990. Figure 2 depicts CC leadership, based on the publications of many reports by the IPCC from 1990-2007 and the author's conceptualization.

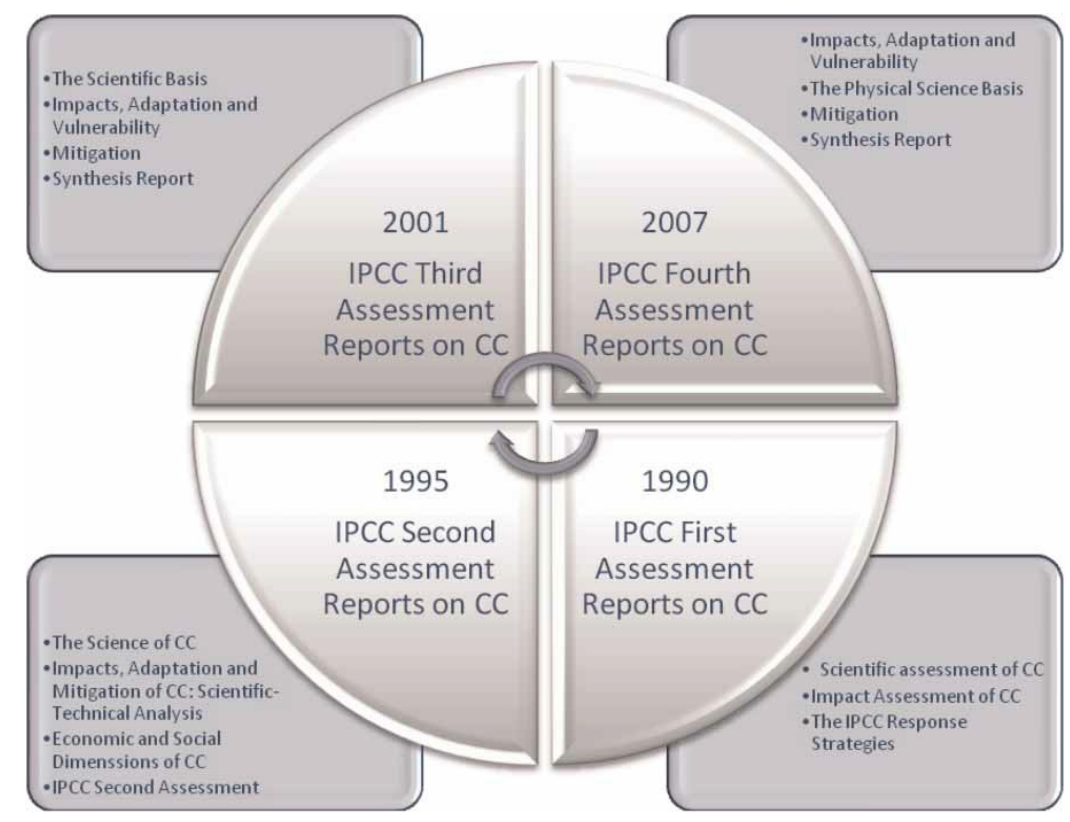

Figure 2. Synthesis of IPCC Assessment Reports (1990-2007) 
Other reports of value not represented in Figure 2 as noted from the IPCC website include three 1992 Supplementary Reports; The Regional Impacts of Climate Change: An Assessment of Vulnerability (1997); a 1999 report, Aviation and the Global Atmosphere; two 2000 reports, Methodological and Technological Issues in Technology Transfer, Emissions Scenarios and Land Use, Land-Use Change, and Forestry; as well as two 2005 reports, Carbon Dioxide Capture and Storage and Safeguarding the Ozone Layer and the Global Climate System: Issues Related to Hydrofluorocarbons and Perfluorocarbons (IPCC, 2009). Although sceptics thought the former US Vice-President Al Gore had a hidden agenda, his movie and book An Inconvenient Truth (Gore, 2006) helped in raising levels of awareness regarding climate change. What makes Al Gore's leadership more pronounced is the fact that he fought a battle against a sceptical former President George W. Bush, Jr. Today, the level of awareness of global warming and CC has undoubtedly increased due to this historical clash. People of all ages, races, colours and from different sectors saw Al Gore's movie, which certainly had an impact on the public and mass discourse on this issue.

The Iraq War disaster aside, Tony Blair and the UK are undoubtedly CC leaders and champions that have inspired and will continue to inspire global business and other leaders in this arena. The UK became the first country to enact a Climate Change Act (2008). Another leader from the UK is Sir Nicholas Stern, who produced the first report linking politics, CC and economics (Stern, 2006). Although not fully recognized as a climate leadership torch-bearer globally, South Africa deserves special mention in the climate change space as an emerging champion. The country has helped to bridge the divide between the countries of the North and South. This has been enhanced by its involvement in the climate space with the $\mathrm{G5}$, G8, G77, G77 P China and Africa Group as well as the nature of its economy and political landscape that fits well with both the developed North and the developing South. South Africa's position in climate leadership is informed by the fact that developing economies must not be forced GHG emission reduction targets post- Copenhagen. However, South Africa advocates the need to have developing countries share responsibility proportionally, taking into account historical GHC emissions - the principle of differentiated but common responsibility, as spelt out in the UNFCCC in 1992. The government has shown its leadership through the development of a Long Term Mitigation Scenario (LTMS) of 2007 (DEAT, 2007), a first in many respects for an emerging economy. The LTMS recognizes a set-up whereby South Africa's GHC emission will peak (continue to increase) in the next two decades, plateau around 2030-2035 and start to decline thereafter. This path is recognized as the one most sustainable in terms of projected growth and 
the major source of energy (coal-fired electricity) powering the growth. The development of the LTMS has witnessed similar initiatives from countries like South Korea, India, Brazil, Mexico and China.

In terms of climate negotiations, South Africa places itself in the Africa Group and the G77 P China. However, there has been an increasing demand for South Africa to engage the climate space with other networks that include the G5, G8, G8 p 5 (G13) and the G20. South Africa's most recent position on CC is explained by President Jacob Zuma's speech to the UN Secretary General's High Level Summit on CC, which took place on 22 September 2009 in New York. The meeting focused on building bridges for a new climate deal post-2012. President Zuma raised key issues regarding climate leadership in general and South Africa, specifically. He said that there was a need to move swiftly and to ensure there would be a new climate treaty. He cautioned:

The global agreement should be guided by a shared vision. It should be inclusive, fair and effective. It must recognise that solving the climate problem cannot be separated from the struggle to eradicate poverty. ... On mitigation, the agreement must contain ambitious, quantified, and legally binding emission reduction commitments by developed countries. It must set the framework for mitigation actions by developing countries that are supported and enabled by finance and technology. ... O Our goal should be to significantly reduce emissions across the globe without constraining development in the countries of the South. (Zuma, 2009, p. 1)

The failure by South Africa to pledge GHG emission reduction targets postKyoto can be viewed by some as weak political leadership in the climate space. This is mainly due to the fact that the country has a very high carbon footprint, emitting GHGs surpassing other countries with quotas specified under the current Kyoto Protocol regime. This can therefore be recorded as a failure in leadership. A GHG emission reduction target for South Africa, no matter how small, could have gone a long way.

\section{Co-leader(ship): an historical account}

A comprehensive historical analysis of co-leaders in the corporate and other circles is presented by David A. Heenan and Warren Bennis in their classic 1999 work Co-Leaders: The Power of Great Partnerships. They identify several co-leaders, including: Bob Eaton and Bob Lutz of Chrysler Corporation; cyber stars Steve Ballmer and Bill Gates; Winthrop H. Smith; Chou Enlai; George C. Marshall; Bernice Pauahi Bishop; Anne Sullivan Macy; Al Gore; Bill Guthridge; Amy Tucker; and Dr Watson and Sherlock Holmes (p. v). Heenan and Bennis $(1999$, p. 3) make a case for the need 
to separate leaders (what I consider 'queen mother' or 'ceremonial' types) and co-leaders (what I term 'busy-bee' or 'worker' types). The world usually sees the queen mother type of leaders, hence the popularity of Bill Gates and not his co-leader Steve Ballmer, according to the authors. The authors claim that "every successful organization has, at its heart, a cadre of co-leaders-key players who do the work, even if they receive little of the glory' (p. 3). Hence in terms of CC, we must look beyond leaders and leading institutions such Tony Blair, Al Gore, the UNFCCC, the IPCC, the UK and EU if we are to succeed in addressing CC. These are the 'queen mother' type of leaders in CC. Discourses around CC are now more complex and as such teams of capable and dedicated leaders and co-leaders working in collaboration are required to get the job done. The epoch of leadership monopoly and glory-earning cannot be replayed in the CC space today.Drawing from Heenan and Bennis (1999, pp. $5-8)$ the following concepts can be identified as defining co-leadership:

- Co-leadership is a tough-minded strategy that will unleash hidden talent in addressing CC challenges.

- Co-leadership is inclusive and gives recognition to those who undertake the realwork, not leaders who merely present the vision in addressing CC. . Co-leadership should permeate all institutions dealing with CC, from the local through national and regional to the global level-power and responsibility inaddressing $\mathrm{CC}$ is dispersed (the concept of powersharing).. Co-leaders share values and aspirations driven by a desire to curtail global warming and negative CC impacts as the common good.. Many can be co-leaders, provided there is desire, particularly from the leaders and/or champions to let such people into the networks and recognize their value.. Co-leaders are often more capable than those above them and can easily closethe gap between them and those on the top in terms of the CC space. . In CC, co-leaders are inevitable as they help address other necessary but usually overlooked aspects of the phenomenon. . Co-leaders are readily available for continuity purposes as they can replace the leaders if need be. The Copenhagen 'rapture' has ushered in such new crop of co-leaders in CC, such as Brazil, China, India and South Africa.

\section{A co-leadership model for CC governance}

The International Centre for Climate Governance (2009, p. 1) reported that during an informal meeting held in Prague in April 2009, the EU environment ministers offered: the United States and other developed nations 'co-leadership' in the fight against global warming if they were to match the aviation $\mathrm{CO}_{2}$ emissions through a global sectoral agreement, with global target set for the aviation sector and facilitate through an emission trading scheme. 
What the above quotation implies is that there is leadership and coleadership. In this case, the EU provides the leadership and believes it can incorporate the USA and other developed countries as co-leaders. The exclusion of developing countries (including powerful ones like the G5) in the proposed co-leadership model was also possibly informed by the fact that the Kyoto Protocol arrangement did not force such countries to reduce their GHGs. It could also be informed by the EU's need to continue to dominate the CC space. Based on the leadership models discussed earlier and the candid articulation of torch-bearers and forerunners, Table 1 provides a platform and proclaims a modified form of CC leadership model - the Co-leadership Model. Over the past half -decade, we have witnessed CC leadership emerging in all of the 10 models conceptualized in Table 1. Since debates on which model is the best 
Table 1. Conceptualization of Co-leadership Model in CC

\begin{tabular}{|c|c|c|}
\hline $\begin{array}{l}\text { Model and/ or } \\
\text { Leader }\end{array}$ & Strength & $\begin{array}{l}\text { Co-Leadership } \\
\text { as Hybrid }\end{array}$ \\
\hline Visionary & $\begin{array}{l}\text { Founders and/or reformers of } \\
\text { CC leadership institutions }\end{array}$ & $\begin{array}{l}\text { Can be poor mangers and } \\
\text { growers of } \mathrm{CC} \text { leadership } \\
\text { institutions } \\
\text { Leave a trail of wounded and }\end{array}$ \\
\hline Political & $\begin{array}{l}\text { Prompt others to act leading } \\
\text { to positive } C C \text { revolutions }\end{array}$ & $\begin{array}{l}\text { dissatisfied CC soldiers Limited } \\
\text { action and practical solutions }\end{array}$ \\
\hline Teaching & $\begin{array}{l}\text { Stimulates others to take up } \\
\text { CC leadership through }\end{array}$ & to addressing $C C$ \\
\hline & teaching and creative & $\begin{array}{l}\text { Lack of experience and wisdom } \\
\text { leading to rushed } C C \text { decisions }\end{array}$ \\
\hline Youthful & $\begin{array}{l}\text { CC followers inspired by CC } \\
\text { leadership passion and } \\
\text { energy }\end{array}$ & $\begin{array}{l}\text { Those not willing to address } \\
\text { CC looked down upon and at }\end{array}$ \\
\hline Spiritual & Followers led into deeper & $\begin{array}{l}\text { tImes seen as outcast and } \\
\text { misfits }\end{array}$ \\
\hline & $\begin{array}{l}\text { sense of CC leading to } \\
\text { significant progress in } \\
\text { addressing it }\end{array}$ & $\begin{array}{l}\text { They are passive as most CC } \\
\text { ideas are inherited }\end{array}$ \\
\hline Inherited & $\begin{array}{l}\text { Give rise to new } C C \text { leaders } \\
\text { who can bring about positive } \\
\text { change }\end{array}$ & $\begin{array}{l}\text { Not good listeners and CC } \\
\text { followers can be used without } \\
\text { capacity development }\end{array}$ \\
\hline Military & $\begin{array}{l}\text { Can accomplish much in } \\
\text { terms of addressing } C C \text { in a } \\
\text { very short period of time }\end{array}$ & $\begin{array}{l}\text { Relationships may suffer, } \\
\text { leading to inefficiency in CC } \\
\text { delivery }\end{array}$ \\
\hline Administrative & $\begin{array}{l}\text { Good CC institutions and } \\
\text { managers ensure that } \\
\text { necessary } C C \text { issues are dealt } \\
\text { with on time }\end{array}$ & $\begin{array}{l}\text { Damage to CC leadership } \\
\text { reputation in the eyes of the } \\
\text { public and critics }\end{array}$ \\
\hline Greedy & $\begin{array}{l}\text { The world can still accomplish } \\
\text { its CC goal under such } \\
\text { leadership }\end{array}$ & $\begin{array}{l}\text { At times the mentoring process } \\
\text { fails to produce the required } \\
\text { Product }\end{array}$ \\
\hline Mentoring & $\begin{array}{l}\text { CC followers are developed as } \\
\text { CC champions }\end{array}$ & $\begin{array}{l}\text { At times the mentoring process fails to } \\
\text { produce the required product }\end{array}$ \\
\hline
\end{tabular}



will continue, one must remind readers that all the models have a contribution to make in addressing CC, particularly within a co-leadership setup. Further clarity is found when one considers decoupling leaders from leadership. The decoupling removes us from the linear thinking of looking at leaders as people who are always in front, to leadership as inclusive of leaders from the back, middle and front as well as having what I term a 'Leadership Narrative/Nehicle'. As already suggested, co-leadership realizes the existence of a leadership vehicle in which individual leaders are separated from leadership. Individual leaders come and go as they are allocated or avail themselves to specific leadership zones whose critical mass is driven from the leadership vehicle in the context of this paper-Global Warming and CC. Hence the Global Warming and CC leader- ship vehicle demands that leaders take up co-leadership in various CC leadership zones, including: mitigation, adaptation, policy and legal frameworks, technology, financing, social dynamics and research and development (R\&D).All the identified leadership zones revolve around the leadership drive-global warming and CC as presented in Figure 3. The co-leadership model might be the best, especially given the complex and contested nature of CC. Some leaders within specific CC leadership zones might fail while others succeed. The coleadership model proposed here can be applied at various levels ranging from as low as the household and neighbourhood through to he corporate, nationaland, ultimately, global scale. The co-leadership CC model requires that leaders and co-leaders identify their niches of influence or be volunteered to such. In concluding their book on co-Leaders, Heenan and Bennis (1999, pp. $263-282$ ) write lessons for co-leaders. They talk of a need to establish a good relation-ship between leaders and co-leaders. The same must apply in the CC co-leadership model. This could be the reason why the EU has extended a hand of "co-leadership'in CC to the USA and other developed countries, as discussed elsewhere in the paper. In co-leadership, labour in addressing CC challenges must be shared fairly according to the common but differentiated responsibilities and capabilities. This means that developing countries still have roles and duties that they can play if they are permitted space and their capabilities are recognized by the developed countries. Although there are disagreements such as those witnessed during the Copenhagen Climate Summit, these must be resolved, according to Heenan and Bennis (1999, p. 263), 'without acrimony and without loss of mutual respect'. 
Heenan and Bennis (1999, pp. 64-273) provide a checklist for co-leaders (still applicable in many respects to the proposed CC xo-Leadership model as amended here). The checklist spells out that as co-leader one should:

- Know yourself (be it individuals, countries or groupings)

- Know your leader

- Avoid clashes in deliberations and proposed action pointers

- Give leaders what they need as well as what they want

- Find out how to address challenges to the best of your ability

- Do not compromise your positions

- Lead as well as follow

- Know when to stay put, when to put brakes and when to start the cycle -be a policy entrepreneur

- Define breakthroughs on own terms although the terms must address the collective

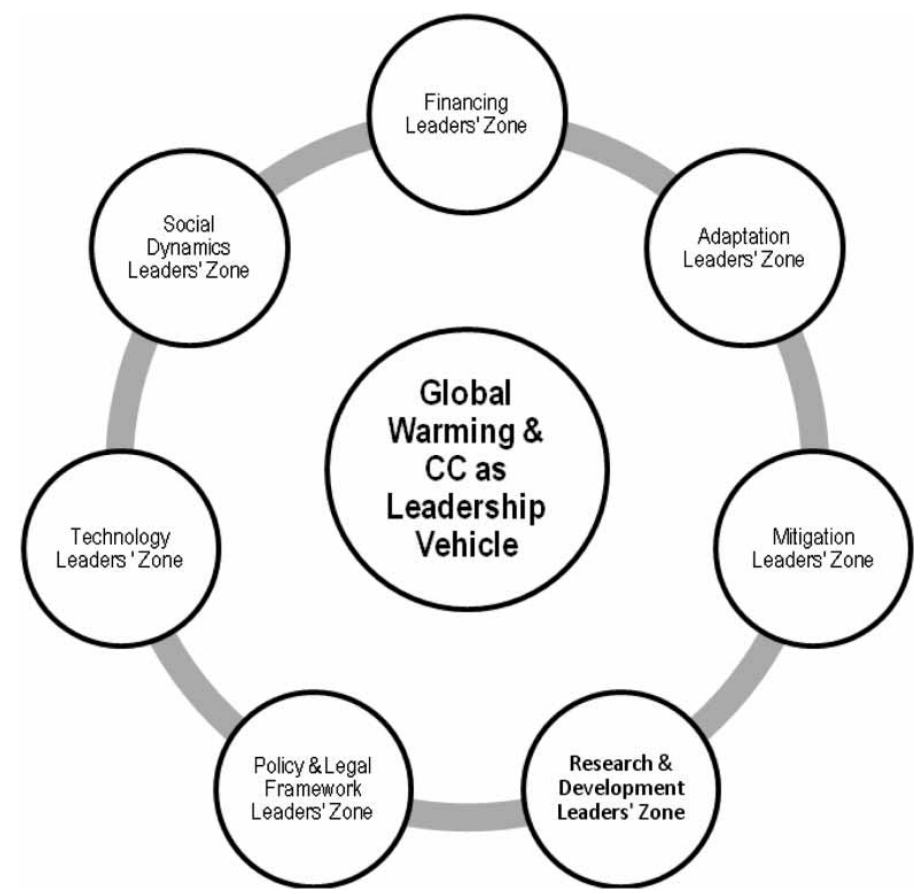

Figure 3. CC Leadership Vehicle and Leadership Zones in Coleadership (author)

It is also important to realise what makes up the ' $\mathrm{co}$ ' in co-leadership. The National Leadership of School and Children's Services (NCSL) (2009, p. 3) notes that at the ' $x O$ ' in the co-leadership relationship is the need to '[s]hare the jobs and make sure the tasks get finished, make sure the co- 
leaders are moving, make sure that co-leaders are grounded (in CC discourses) and that there are skills among the co-leaders'. In so doing, one must be careful to avoid co- leadership fatigue, as some leaders might relegate and negate their roles by appointing co-leaders. In line with the theme of this paper, co-leadership calls for a different kind of delegation-delegating to share responsibility and skills and to address complexity in CC.

\section{Conclusion}

Co-leadership has been discussed as a potentially appropriate model for addressing the challenges of climate change in our generation. The model realizes the existence of leaders and co-leaders who must work together towards a collective climate change position bearing in mind their common but differentiated responsibilities and capabilities. The model also recognizes the existence of leadership and co-leadership. Al Gore, Tony Blair, Sir Nicholas Stern and Barack Obama are some of the leaders identified as torch-bearers in addressing climate change. In terms of institutions: the United Nations Framework Convention on Climate Change (and the Kyoto Protocol), the Intergovernmental Panel on Climate Change and the International Energy Agency were cited. In climate change, co- leadership realises that the climate change narrative is at the core driving various kinds of leadership tied to numerous leadership zones. Among some of the leadership zones making up the climate change co-leadership model are: the mitigation leadership zone, the adaptation leadership zone, financing leadership zone, technology leadership zone, social dynamics zone, policy and legal frame- work leadership zone, as well as the research and development leadership zone. The paper used the Actor/Actant-Network Theory for documenting, understanding, analysing and conceptualizing CoLeadership in climate change.

\section{Acknowledgements}

The author thanks Exxaro Resources Limited for sponsoring the Chair in Business and Climate Change run under Unisa's Centre for Corporate Citizenship.

Note

Exxaro Chair of Business \& Climate Change, Centre for Corporate Citizenship, University of South Africa, PO BOX 392, UNISA, 0003. Email: nhamog@unisa.ac.za 


\section{References}

Arendt, P. (2007), Leadership Models in the Bible (Raleigh, CT: Mentorlink International).

Billsberry, J. (2009), 'Leadership: A Contested Construct', in: J. Billsberry (ed.), Discovering Leadership (London: Palgrave Macmillan).

Bolden, R. (2004), What is Leadership? (Exeter: University of Exeter Centre for Leadership Studies).

Bolden, R. (2005), What is Leadership Development? (Exeter: University of Exeter Centre for Leadership Studies).

Callon, M. (1986), 'Some Elements of a Sociology of Translation: Domestication of the Scallops and the Fishermen of St Brieuc Bay', in: J. Law (ed.), Power, Action and Belief: A New Sociology of Knowledge (London:Routledge \& Kegan Paul).

Callon, M. (1991), 'Techno-Economic Networks and Irreversibility', in: J. Law (ed.), A Sociology of Monsters: Essays on Power, Technology and Domination (London: Routledge).

Callon, M. (1999), 'Actor-Network Theory: The Market Test', in: J. Law and J. Hassard (eds), Actor Network Theory and After (Oxford: Blackwell Publishers).

Callon, M. and Latour, B. (1981), 'Unscrewing the Big Leviathan: How Actors MacroStructure Reality and How Sociologists Help Them To Do So', in: K. Knorr-Cetina and A.V. Cicourel (eds), Advances in Social Theory and Methodology: Toward an Integration of Micro- and Macro-Sociologies (Boston, MA: Routledge).

Davies, R.A. (2002), 'Power, Politics and Networks: Shaping Partnerships for Sustainable Communities', Area, 34(2), pp. 190-203.

Department of Environmental Affairs and Tourism (DEAT) (2007), Long Term Mitigation Scenarios (Pretoria:

Department of Environmental Affairs and Tourism).

Fountain, R-M. (1999), 'Socio-Scientific Issues via Actor Network Theory', Journal of Curriculum Studies, 31(3), pp. 339-358.

G20 (2009), 'Leaders' Statement: The Pittsburgh Summit. September 24-25 2009' (Pittsburgh: G20 Secretariat).

Gaskell, J. and Hepburn, G. (1998), 'The Course as Token: A Construction of/by Networks', Research in Science Education, 28(1), pp. 65-76. 
Gill, R. (2006), Theory and Practice of Leadership (London: Sage Publications).

Grobler, F. (2009), 'Mbeki: Experts Failed To Predict Financial Crisis'. Available online at: http://www.mg.co. za/article/2009-09-23-mbeki-experts-failed-to-predictfinancial-crisis

Gore, A. (2006), An Inconvenient Truth: A Global Warning (London: Bloomsbury).

Heenan, A.D. and Bennis, W. (1999), Co-Leaders: The Power of Great Partnerships (New York: John Wiley \& Sons).

International Centre for Climate Governance (2009), 'EU Environment Ministers Offer "Co-Leadership” On Climate', Climate Policy News, pp. 1-2.

Intergovernmental Panel on Climate Change (IPCC) (2009), 'Reports'. Available onlineat:http://www.ipcc.ch/publications_and_data/publications_and_data_reports. htm\#1

Keeley, J. and Scoones, I. (2003), Understanding Environmental Policy Processes: Cases from Africa (London: Earthscan).

Latour, B. (1986), 'The Power of Association', in: J. Law (ed.), Power, Action and Belief: A New Sociology of Knowledge? (London: Routledge \& Kegan Paul).

Latour, B. (1993), We Have Never Been Modern (Cambridge, MA: Harvard University Press).

Latour, B. (1999), 'On Recalling ANT', in: J. Law and J. Hassard (eds), Actor Network Theory and After (Oxford: Blackwell).

Law, J. (1999), 'After ANT: Complexity, Naming and Topology', in: J. Law and J. Hassard (eds), Actor Network Theory and After (Oxford: Blackwell).

Lotz-Sisitka, H. (2006a), 'Participating in the UN Decade of Education for Stainable Development: Voices in a Southern African Consultation Process', Southern African Journal of Environmental Education, 23, pp. 10-33.

Lotz-Sisitka, H. (2006b), 'Tracing Actors, Actants and Relational Dynamics in Environmental EducationResearch', Southern African Journal of Environmental Education, 23, pp. 5-9.

National Leadership of School and Children's Services (NCSL) (2009), 'Co-leadership: Origins, Beliefs and Practice'. Available online at: http://www.networkedlearning.ncsl.org.uk/knowledge. ./coleader- originoicsei.doc 
Nhamo, G. (2003), 'South Africa's Waste Management Policy Implementation: Emerging Stakeholder Participation Paradoxes', Southern African Journal of Environmental Education, 20, pp. 37-50.

Nhamo, G. (2006a), 'Why Can't We Clean Up Our Own Act?', South African Labour Bulletin, 30, pp. 10-13.

Nhamo, G. (2006b), 'Actor/Actant-Network Theory As Emerging Methodology For Environmental Education in Southern Africa', Southern African Journal of Environmental Education, 23, pp. 34-47.

Nhamo, G. (2008), 'Regulating Plastics Waste, Stakeholder Engagement and Sustainability Challenges in South Africa', Urban Forum, 19(1), pp. 83-101.

Oltmann, J. (2008), 'This Project Needs a Leader-Now!', PM World Today, X, pp. $1-4$.

Philips, D. (2009), 'The Similarities and Differences between four Leadership Models and How They Might Address Contemporary Leadership Issues and Challenges' (Georgetown: Swill Management Centre University).

Shanahan, M. (2007), A Journalist's Guide to the Bali Climate Conference (London: International Institute for Environment and Development).

Singleton, V. and Michael, M. (1993), 'Actor-Networks and Ambivalence: General Practitioners in the UK Cervical Screening Programme', Social Studies of Science, 23(2), pp. 227-264.

Stern, N. (2006), The Stern Review Report on the Economics of Climate Change (Warwick: University of Warwick).

Stogdill, M.R. (1974), Handbook of Leadership: A Survey of Theory and Research (New York: Free Press).

Tatnall, A. and Gilding, A. (1999), 'Actor-Network Theory And Information Systems Research', in: Proceedings of the 10th Australian Conference on Information Systems.

United Nations Environment Programme (UNEP) (2009), Climate in Peril: A Popular Guide to the Latest IPCC Reports (Nairobi: UNEP).

Williams-Jones, B. and Graham, E.J. (2003), 'Actor-Network Theory: A Tool to Support Ethical Analysis of Commercial Genetic Testing', New Genetics and Society, 22(3), pp. 271-296.

Zuma, J. (2009), 'Message by South African President Jacob Zuma to the UN Secretary General's High Level Summit on Climate Change' (Pretoria: The Presidency). 